\title{
Complex glycerol kinase deficiency - long-term follow-up of two patients
} Złożony deficyt kinazy glicerolu - długofalowa obserwacja dwóch pacjentów

\author{
${ }^{1}$ Beata Wikiera, ${ }^{2}$ Aleksandra Jakubiak, ${ }^{3}$ Izabela Łaczmanska, ${ }^{1}$ Anna Noczyńska, ${ }^{2}$ Robert Śmigiel \\ ${ }^{1}$ Department of Endocrinology and Diabetology for Children and Adolescents, Wroclaw Medical University, \\ Poland \\ ${ }^{2}$ Department of Paediatric, Division of Propaedeutic of Paediatrics and Rare Disorders, Wroclaw Medical \\ University, Poland \\ ${ }^{3}$ Department of Genetics, Wroclaw Medical University, Poland
}

\begin{abstract}
Complex glycerol kinase deficiency (CGKD) is a rare genetic syndrome which belongs to the group of contiguous gene syndromes and is caused by microdeletion of genes located in Xp21. Patients with CGKD present with features characteristic for adrenal hypoplasia, glycerol kinase deficiency, Duchenne muscular dystrophy and sometimes intellectual disability. We present a long-term follow-up of two unrelated boys with molecular diagnosis of complex glycerol kinase deficiency. Genetic examinations in both patients revealed a deletion on Xp21 chromosome including complete deletion of NROB1 and GK genes. Additionally in patient 2 IL1RAPL1 genes were deleted. In separate MLPA test DMD gene deletion was diagnosed in both patients as follow: in patient 1 whole gene while in patient 2 the C-terminal region of $D M D$ was deleted. Although the first symptom in both was salt loss syndrome, the course of the disease was different for them. We share our experience resulting from the opportunity of caring for patients with this rare disease from the beginning of their life to the end of pediatric care.
\end{abstract}

Key words:

glycerol kinase deficiency, congenital adrenal hypoplasia, muscular dystrophy.

\begin{abstract}
Streszczenie
Złożony niedobór kinazy glicerolowej (CGKD) to rzadki zespół genetyczny należący do grupy zespołów genów sąsiadujących, spowodowany mikrodelecją genów zlokalizowanych na chromosomie Xp21. Pacjenci z CGKD mają cechy charakterystyczne dla hipoplazji nadnerczy, niedoboru kinazy glicerolowej, dystrofii mięśniowej Duchenne'a, a czasem niepełnosprawności intelektualnej. W pracy przedstawiono długofalową obserwację dwóch niespokrewnionych chłopców z rozpoznaniem molekularnym złożonego niedoboru kinazy glicerolowej. Badania genetyczne u obu pacjentów wykazały delecję na chromosomie Xp21, w tym całkowitą delecję genów NROB1 i GK. Dodatkowo u pacjenta 2. występowała delecja genu IL1RAPL. W oddzielnym teście MLPA u obu pacjentów rozpoznano delecję genu DMD: u pacjenta 1. całego genu, u pacjenta 2. regionu C-końcowego DMD. Chociaż pierwszym objawem w obu przypadkach był zespół utraty soli, przebieg choroby u obu pacjentów się różnił. Dzielimy się naszym doświadczeniem wynikającym z możliwości opieki nad pacjentami z tą rzadką chorobą od początku ich życia do końca opieki pediatrycznej.
\end{abstract}

Słowa kluczowe:

deficyt kinazy glicerolu, wrodzona hipoplazja nadnerczy, dystrofia mięśniowa.

\section{What is already known on this topic?}

The genetic background is well known despite the rare occurrence of complex glycerol kinase deficiency. The first clinical signs are related to congenital adrenal hypoplasia, while glycerol kinase deficiency and Duchenne muscular dystrophy manifest later in life.

Received: 21.03.202

Accepted: 12.05 .2021

Conflict of interests: none declared.

\section{What this study adds?}

This is the first report on the full pediatric care of two unrelated patients with complex glycerol kinase deficiency. It emphasizes the diversity of the clinical course of the disease. We hope it will prove to be of help to other endocrinologists to the benefit of our patients. 


\section{Introduction}

Complex glycerol kinase deficiency (CGKD, OMIM: 300679, ORPHA: 261476) is a rare genetic syndrome which belongs to the group of contiguous gene syndromes and is caused by microdeletion of genes located in Xp21 critical chromosomal region. The clinical image of the disease depends on its size and range of deletion [1]. CGKD is inherited as the X-linked recessive disorder, therefore predominately affects males. To the group of genes involved in this syndrome belong: DMD (OMIM: 300377, ORPHA:), GK (OMIM: 300474, ORPHA:), NROB1 (OMIM: 300473, ORPHA:), IL1RAPL1 (OMIM: 300206) [2]. In order to diagnose CGKD at least two genes should be located in chromosome deleted region but in most cases deletion of three following genes is found - DMD, GK and NROB1 [3]. The frequency of ILIRAPL1 deletion in CGKD patients is not known.

Patients with CGKD present features characteristic for adrenal hypoplasia, glycerol kinase deficiency, Duchenne muscular dystrophy and sometimes intellectual disability [4]. Up to date more than 100 cases (mostly boys) of CGKD were described [5].

The aim of study is to present unique long-term observation of two unrelated boys with molecular diagnosis of complex glycerol kinase deficiency from the beginning of life to the end of pediatric care.

\section{Clinical report}

Patient 1.

A male infant was born after 37 weeks of gestation from first pregnancy with birth weight $2950 \mathrm{~g}$, length $53 \mathrm{~cm}, 9$ Apgar score. His parents were young and unrelated. He was referred to hospital in $5^{\text {th }}$ week of life due to failure to thrive, loss of body weight, athrepsia, dehydration, weak muscle tone, and clinical features of the respiratory tract infection. Results of laboratory tests revealed severe dyselectrolytemia (sodium $116.6 \mathrm{mmol} / \mathrm{l}$, potassium $6.13 \mathrm{mmol} / \mathrm{l}$ ), and metabolic ketoacidosis. A preliminary diagnosis of the adrenal insufficiency was confirmed by the results of hormonal tests. Basal concentrations were as follows: ACTH 162 ng/l, (normal value < 45), cortisol 46.92 nmol/l (17-hydroxyprogesterone (17OHP) $0.11 \mathrm{nmol} / \mathrm{l}$, aldosterone $0.9 \mathrm{nmol} / \mathrm{l}$, plasma renin activity (PRA) $153.8 \mathrm{mlU} / \mathrm{l}$. After ACTH stimulation cortisol response was poor and has reached the value $77.28 \mathrm{nmol} / \mathrm{l}$. Urinary steroid profile (GC-MS, gas chromatography - mass spectrometry method) was performed unfortunately on first hydrocortisone administration and confirmed excessive excretion of THS (tetrahydrosteroids), THDOC (tetrahydrodeoxycorticosterone), reduced excretion THAldo (tetrahydroaldosterone). Ultrasound imagining did not reveal any abnormalities in the cerebral structures, normal picture of the abdominal cavity, scrotal location and normal structure of the testicles. After starting fluid, electrolyte, hydrocortisone and fludrocortisone treatment, the patient's condition improved, normalization of laboratory results was observed. Neurological examination found muscle tension within normal limits but positional asymmetry was noticed and rehabilitation was recommended.
During first year of life several infections of respiratory and urinary tract without adrenal decompensation have been reported. This may explain the rare occurrence of follow-up visits and irregular rehabilitation but does not explain irregular hormonal substitution. As the result at the age of 1 year, the patient weighed only $5.88 \mathrm{~kg}$ with length $67 \mathrm{~cm}$. Psychomotor development was delayed. His sodium level was low (132 mmol/l). The child was admitted to hospital for revision of the diagnosis. Primarily celiac disease has been suspected, and excluded. Because of high level of serum creatine phosphokinase (CPK $13126 \mathrm{U} / \mathrm{l}$, normal value < $154 \mathrm{U} / \mathrm{l}$ ) and abnormal electromyography (correct sensory conduction, motor conduction: lower amplitude of the response from both peritoneal nerves) Duchenne muscular dystrophy was considered. The examination of lipids confirmed hyperlipidemia with concentration of cholesterol $5.49 \mathrm{mmol} / \mathrm{l}$, and triglycerides $7.2 \mathrm{mmol} / \mathrm{l}$. Using the GC-MS method excessive excretion of urinary organic acids (glycerol) was found in a sample from 24-hour urine collection. Based on the clinical condition and the obtained results, there was a suspicion of complex glycerol kinase deficiency.

The boy started to sit at the age of 22 months, to stand one month later. At this age, he could speak only single syllables. He was still gaining little weight, at the age of 2 years his weight was $8.3 \mathrm{~kg}$ and height $75 \mathrm{~cm}$. At 2 years the bone age was 9 months. Thyroid function was correct. At the age of 2.5, he began to work held by hand.

Magnetic resonance imaging (MRI) of the head at the age of four showed delated cerebral fluid spaces in the frontal region to $0.4 \mathrm{~cm}$ otherwise, the correct image of the brain. The boy demanded frequent hospitalizations for respiratory tract infections in subsequent years. No occurrence of adrenal crisis was observed. At the age of eight calf muscle hyperplasia and upper limb muscle atrophy was visible. A loss of walking ability was preceded by contusion of the left ankle at the age of 10 . Values of CPK fluctuated (6617-29861 U/I), as well as CK-MB (326-598 U/l, normal value < $25 \mathrm{U} / \mathrm{I})$. However, electrocardiogram and cardiac ultrasound were normal until the age of 10 . Progressive muscular atrophy led to the development of dilated cardiomyopathy and was the direct cause of the patient's death in the course of sepsis at the age of 13. Puberty did not start.

\section{Patient 2}

This patient was a son of healthy, unrelated parents. Prenatal period was uneventful. The boy was born from second pregnancy, after 41 weeks of gestation, through cesarean section, with normal birth parameters (weight $2900 \mathrm{~g}$, length $52 \mathrm{~cm}$, Apgar score 9). After birth no problems were observed, except mild intraventricular hemorrhage found in head ultrasonography. In the $5^{\text {th }}$ week of life, dehydration, adynamia and failure to thrive occurred. During hospitalization low sodium (123 mmol/l) and high potassium (6,1 mmol/l) level, metabolic acidosis and anemia were found. On a base of elevated plasma ACTH level, subnormal cortisol level, low aldosterone level and analysis of urine steroid profile diagnosis of primary adrenal insufficiency was established. Fluid, electrolytes, and hydrocortisone treatment led to the improvement of patient's condition as well as to 
normalization of laboratory results. Ultrasound imagining of the cerebral structures and the abdominal cavity did not revealed any abnormalities. Despite the therapy and rehabilitation, patient's psychomotor development was delayed: he started walking with support at the age of 23 months and spoke only single syllables. In the following years, the condition was stable and he regularly reported for health checks.

At the age of five, the boy's condition deteriorated suddenly with vomiting, hypovolemia, disturbance of consciousness. He demanded therapy in the intensive care unit. Magnetic resonance imaging (MRI) of the head showed an ischemic stroke of the left hemisphere. At $6^{\text {th }}$ year of life, elevation of serum creatine phosphokinase (CPK $4236 \mathrm{U} / \mathrm{l})$ and triglycerides $(6.66 \mathrm{mmol} / \mathrm{l})$ was detected. The patient's electrocardiogram and cardiac ultrasound examination were normal. Decrease of muscle strength was observed but without calf muscle hyperplasia. However, the patient remained under the control of a neurologist, cardiologist, and gastroenterologist. An additional problem constitutes esophagitis requiring treatment with proton pump inhibitors.

The pubertal development started at the age of 13 years and was scant: pubic hair 2 stage according to Tanner scale, and testicular volume below 4 , without progression of puberty. Low plasma level of LH (1.08 IU/l; normal range 0.8-9.0) FSH (1.31 $\mathrm{U} / \mathrm{l}$; normal range 1.2-7) and testosterone (2.84 nmol/l; normal range 9.09-41.64). Lack of progression of puberty in the following years indicated hypogonadotropic hypogonadism requiring testosterone substitution.

The patient was switched do endocrinologist for adults at the age 18 .

\section{Molecular report}

Genetic examinations (series MLPA tests described below) in both patients revealed a deletion on Xp21 chromosome including complete deletion of NROB1 and GK genes. Additionally in patient 2 ILIRAPL1 genes were deleted. In separate MLPA test $D M D$ deletion was diagnosed in both patients as follow: in patient 1 whole gene while in patient 2 the $C$-terminal region of $D M D$.

Multiplex Ligation-dependent Probe Amplification was performed using the SALSA MLPA probemix P106-B2 MRX (MRCHolland, Amsterdam, the Netherlands), that contains MLPA probes for 16 genes located on the $X$ chromosome, described as associated with non-specific $X$-linked mental retardation (MRX): RPS6KA3, ARX, ILIRAPL1, TSPAN7, PQBP1, HUWE1, OPHN1, ACSL4, PAK3, DCX, AGTR2, ARHGEF6, FMR1, AFF2 (FMR2), SLC6A8 and GDI1. The MLPA reaction was prepared using the TC512 thermocycler (Techne Inc. Burlington, NJ) strictly according to the producer's protocol.

The MLPA products were separated during capillary electrophoresis using the ABI 310 Genetic Analyser with the GeneScan Analysis software version 3.1.2 (ThermoFisher Scientific, Waltham, MA, USA), the POP-4 Polymer (ThermoFisher Scientific, Waltham, MA, USA) and the GeneScan ${ }^{\text {TM }} 500 \mathrm{LIZ}^{\text {TM }}$ dye Size Standard (ThermoFisher Scientific, Waltham, MA, USA). The analysis of obtained results was performed using the Gen-
eMarker software, version 1.85 (SoftGenetics LLC). For male the lack of signal for a probe and for females 35-50\% reduction in relative peak height were considered as a deletion.

\section{Discussion}

NROB1 gene belongs to the nuclear receptor superfamily involved, among others, in formation of the adrenal glands as the coordinator. NROB1 function is to restrain transcriptional activity of other nuclear receptor genes. Mutations in NROB1 result in adrenal hypoplasia with hypogonadotropic hypogonadism [6]. First symptoms are present in the infancy as failure to thrive, loss of salt leading to adrenal crisis manifested as vomiting and dehydration. ACTH hormone concentration in plasma increases, while concentration of glucocorticoids, mineralocorticoids and androgens are considerably decreased. Hypogonadotropic hypogonadism clinically demonstrates in childhood as small testes or cryptorchidism, in adolescents delayed puberty and lack of secondary sexual signs or pubertal arrest at third Tanner stage is observed. Males are always infertile [7].

Complex glycerol kinase deficiency was firstly described by McCabe et al. in two brothers with glyceroluria, growth retardation, strabismus, osteoporosis and intellectual disability [1]. In 1985 two different groups of scientist revealed a deletion of Xp21 chromosome region in patients with combination of glycerol kinase deficiency, adrenal hypoplasia and Duchenne muscular dystrophy [8]. Genes located in region Xp21 were mapped as following IL1RAPL1, NROB1, GK, DMD [2]. The symptoms of particular patient depend on size of deletion and the list/sort of included genes. The disruption of GK gene is responsible for glycerol kinase deficiency. Mutations and deletions in this gene correlates with variable clinical effect ranging from hyperglycerolaemia and pseudohypertriglyceridaemia in asymptomatic males to severe metabolic crisis with vomiting, metabolic acidosis, hypoglycemia, loss of consciousness, seizures accompanied with growth retardation, delayed psychomotor development, bone dysplasia in childhood. Crisis appears during episodes of increased catabolism like for example: fasting, exercise or infections [9].

In both patients at the beginning, primary adrenal insufficiency was established. Also in both presented patients complete deletion of GK and NROB1 genes was diagnosed. The patients needed multiple hospitalization and showed symptoms of metabolic crises in infancy.

$D M D$ gene encodes dystrophin, large protein present in all skeletal muscles, heart and brain and responsible for proper functioning of skeletal muscles. Mutations in DMD gene affect especially skeletal muscles and a heart and result in two diseases: Duchenne muscular dystrophy or Becker muscular dystrophy [10]. Duchenne muscular dystrophy is more common and more severe than Becker muscular dystrophy. Usually symptoms are visible for parents in $2^{\text {nd }}-3^{\text {rd }}$ year of life as abnormal gait, problems with climbing and toe-walking. Weakening of muscles is progressive and leads to lose ability of walking usually in $12^{\text {th }}$ year of life and also to dilated cardiomyopathy and severe weakness of respiratory muscles. Patients die because 
of respiratory or cardiac distress in their early twenties. Some of them present learning difficulties or intellectual disability. In serum, creatine kinase is highly elevated. Electromyography shows myopathic abnormalities [11].

In patient 1 whole $D M D$ gene deletion, while in patient 2 partial $D M D$ gene deletion was revealed. Both deletions lead to complete inactivation of DMD protein, and are responsible for severe course of the disease. Both patients presented delayed psychomotor development, problems with walking, abnormal myopathic electromyography and high levels of creatine kinase. Patient 1 had more severe course of the disease, with progressive muscular atrophy, complete loss of ability to walk and severe cardiomyopathy. Patient 2, despite deterioration of muscle strength, during the course of observation did have neither calf hypertrophy nor cardiomyopathy.

IL1RAPL gene is a member of the interleukin-1 receptor family and encodes protein which is expressed in brain neurons. ILIRAPL is involved in outgrowth and functioning of neurite. Deletion of ILIRAPL gene is responsible for intellectual disability [12].

However, intellectual disability may occur even with presence of this gene, as a result of deletion of DMD gene or brain damage caused by episodes of hypoglycemia or constant hyperglycerolemia [13]. Only patient 2 had deletion of IL1RAPL gene, although both of them presented delayed speech development and intellectual disability.

Lifetime of affected males with CGKD is often shortened. The first critical period is infancy or early childhood because of manifestation of adrenal dysfunction which might be misdiag-

\section{References}

1. McCabe E, Guo W, Burris TP. Complex glycerol kinase deficiency a contiguous gene syndrome involving the Duchenne muscular dystrophy, glycerol kinase, and adrenal hypoplasia congenita loci. Mental Retardation and Developmental Disabilities Research Reviews 1996; 2: 160-166.

2. Stanczak CM, Chen Z, Zhang YH, et al. Deletion mapping in Xp21 for patients with complex glycerol kinase deficiency using SNP mapping arrays. Hum Mutat 2007, 28: 235-242. doi: 10.1002/humu.20424.

3. Sjarif DR, Ploos van Amstel JK, et al. Isolated and contiguous glycerol kinase gene disorders: a review. J Inherit Metab Dis 2000; 23: 529-547. doi: 10.1023/a:1005660826652.

4. Wikiera B, Jakubiak A, Zimowski J, et al. Complex glycerol kinase deficiency- X-linked contiguous gene syndrome involving congenital adrenal hypoplasia, glycerol kinase deficiency, muscular Duchenne dystrophy and intellectual disability (IL1RAPL gene deletion). Pediatr Endocrinol Diabetes Metab 2012; 18: 153-157.

5. Heide S, Afenjar A, Edery P, et al. Xp21 deletion in female patients with intellectual disability: Two new cases and a review of the literature. Eur J Med Genet 2015; 58: 341-345. doi: 10.1016/j.ejmg. 2015.04.003.

6. Habiby RL, Boepple P, Nachtigall L, et al. Adrenal hypoplasia congenita with hypogonadotropic hypogonadism: evidence that DAX nosed. Later, patients usually die in their twenties due to respiratory distress [4]. Our first patient died in adolescence due to cardiac complications of DMD in the course of sepsis, second patient, despite a severe metabolic crisis, lived to adulthood.

CGKD occurs de novo in most cases and a patient is usually the first person in the family with this disease, although inheritance from clinically healthy mother can occur. Symptoms are present mainly in males, because CGKD is inherited in a X-linked recessive trait. Females with CGKD are usually healthy carriers that may transfer mutation to offspring. Rarely also females with deletion may present symptoms of the disease, because of skewed inactivation of $X$ chromosome [5]. Both our patients had de novo deletions. Recurrence risk in their families is low described as about 1\%, because it is impossible to exclude germinal mosaicism (presence of mutation only in germ cells). A prenatal diagnosis and genetic counseling should be offered for a mother of the affected boy in each subsequent pregnancy. Successive publications increasing medical knowledge on the clinical and genetic picture of the adjacent gene complex responsible for CGKD facilitate diagnosis at a very early stage of life [14]. Early diagnosis of CGKD gives the patient the possibility of optimal multi-profile medical care, which has a positive effect on the optimal individual development and the quality of life. We hope that our long-term observations covering the entire period of pediatric care will contribute to the improvement of this care. To our knowledge, this is the first report on the full pediatric care of patients with the disease. We hope it will prove to be of help to other endocrinologists to the benefit of our patients.
-1 mutations lead to combined hypothalamic and pituitary defects in gonadotropin production. J Clin Invest 1996; 98: 1055-1062. doi: 10.1172/JCl118866.

7. Seminara SB, Achermann JC, Genel M, et al. X-linked adrenal hypoplasia congenita: a mutation in DAX1 expands the phenotypic spectrum in males and females. J Clin Endocrinol Metab 1999; 84: 4501450-4501459. doi: 10.1210/jcem.84.12.6172.

8. Patil SR, Bartley JA, Murray JC, et al. X-linked glycerol kinase, adrenal hypoplasia and myopathy maps at Xp21. Cytogenet Cell Genet 1985; 40: 720-721.

9. Mak TWL, Wong LM, Wong SN, et al. Glycerol kinase deficiency presenting with hypodipsia, osmotic diuresis and severe hypernatraemia. J Inherit Metab Dis. 2005; 28: 1159-1161. doi: 10.1007/ s10545-005-0101-2.

10. Muntoni F, Torelli S, Ferlini A. Dystrophin and mutations: one gene, several proteins, multiple phenotypes. Lancet Neurol 2003; 2: $731-$ 740. doi: 10.1016/s1474-4422(03)00585-4.

11. Parker AE, Robb SA, Chambers J, et al. Analysis of an adult Duchenne muscular dystrophy population. QJM 2005; 98: 729-736. doi: 10.1093/qjmed/hci113.

12. Gambino F, Pavlowsky A, Béglé A, et al. IL1-receptor accessory protein-like 1 (IL1RAPL1), a protein involved in cognitive functions, regulates N-type Ca2+-channel and neurite elongation. Proc Natl Acad Sci USA 2007; 104: 9063-9068. doi: 10.1073/pnas.0701133104. 
13. Sasaki R, Inamo Y, Saitoh K, et al. Mental retardation in a boy with congenital adrenal hypoplasia: a clue to contiguous gene syndrome involving DAX1 and IL1RAPL. Endocr J 2003; 50: 303-307. doi: 10.1507/endocrj.50.303.

14. Zhang YH, Huang BL, Niakan KK, et al. IL1RAPL1 is associated with mental retardation in patients with complex glycerol kinase

deficiency who have deletions extending telomeric of DAX1. Hum Mutat 2004; 24: 273. doi: 10.1002/humu.9269.

15. Korkut S, Baştuğ O, Raygada M, et al. Complex Glycerol Kinase Deficiency and Adrenocortical Insufficiency in Two Neonates. J Clin Res Pediatr Endocrinol 2016; 8: 468-471. doi: 10.4274/jcrpe.2539. 